\title{
Revista de Psiquiatria Clínica: Novos Rumos
}

Após obter a sua indexação na Scielo no ano de 2003, a Revista inicia este ano de 2004 com importantes modificações formais e estruturais.

A comissão editorial foi reformulada e ampliada com a inclusão de novos nomes do Brasil e do exterior, que contribuirão para manter o alto nível cientifico dos artigos publicados, oferecendo, com seus pareceres, uma verdadeira parceria aos autores de artigos submetidos para consideração.

Foram feitas mudanças nos Editores de área e incluídas três novas áreas específicas, com seus respectivos editores: Revisões da literatura, Novos caminhos em pesquisa e Estatística.

O aspecto visual da Revista foi mudado, procurando torná-lo mais agradável ao leitor.

A partir de 2004, a Revista passa a ser produzida pela SEGMENTO FARMA EDITORES. Em vista desta mudança, feita por motivos operacionais, agradecemos aqui à LEMOS EDITORIAL pela excelente parceria que nos ofereceu na produção da Revista até o momento.

Visamos com estas modificações a aprimorar ainda mais a nossa Revista, para cumprir a sua missão principal de informar os nossos leitores sobre os progressos contínuos pelos quais vêm passando as diferentes áreas de pesquisa e assistência em saúde mental.

Wagner F. Gattaz Editor 